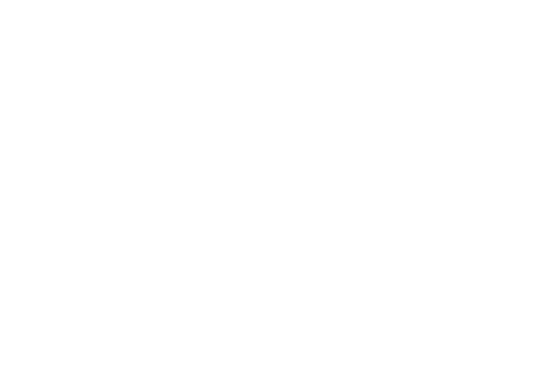

Annu. Rev. Mar. Sci. 2009. 1:117-41

First published online as a Review in Advance on August 28, 2008

The Annual Review of Marine Science is online at marine.annualreviews.org

This article's doi:

10.1146/annurev.marine.010908.163930

Copyright (c) 2009 by Annual Reviews. All rights reserved

1941-1405/09/0115-0117\$20.00

\section{Centuries of Human-Driven Change in Salt Marsh Ecosystems}

\author{
K. Bromberg Gedan, ${ }^{1}$ B.R. Silliman, ${ }^{2}$ \\ and M.D. Bertness ${ }^{1}$
}

${ }^{1}$ Department of Ecology and Evolutionary Biology, Brown University, Providence, Rhode Island 02912; email: Keryn_Gedan@Brown.edu, Mark_Bertness@Brown.edu

${ }^{2}$ Department of Zoology, University of Florida, Gainesville, Florida 32611; email: brs@ufl.edu

\section{Key Words}

ecosystem services, reclamation, eutrophication, consumer control, climate change, restoration

\begin{abstract}
Salt marshes are among the most abundant, fertile, and accessible coastal habitats on earth, and they provide more ecosystem services to coastal populations than any other environment. Since the Middle Ages, humans have manipulated salt marshes at a grand scale, altering species composition, distribution, and ecosystem function. Here, we review historic and contemporary human activities in marsh ecosystems-exploitation of plant products; conversion to farmland, salt works, and urban land; introduction of non-native species; alteration of coastal hydrology; and metal and nutrient pollution. Unexpectedly, diverse types of impacts can have a similar consequence, turning salt marsh food webs upside down, dramatically increasing top down control. Of the various impacts, invasive species, runaway consumer effects, and sea level rise represent the greatest threats to salt marsh ecosystems. We conclude that the best way to protect salt marshes and the services they provide is through the integrated approach of ecosystem-based management.
\end{abstract}




\section{INTRODUCTION}

Humans have influenced all land, marine, and aquatic ecosystems on earth (Vitousek et al. 1997). Here, we evaluate the global distribution and extent of human impacts on the structure and function of coastal salt marshes. More than $40 \%$ of the world's population resides on the world's coasts, which account for just $4 \%$ of the land surface (UNEP 2006). This hyperconcentration at the land-sea interface strains coastal ecological services, particularly in coastal wetlands, which provide more ecological services than any other coastal environment (UNEP 2006). Not surprisingly, salt marshes have experienced intense and varied human impacts that range from reclamation, waste disposal, and livestock grazing to less obvious contemporary impacts, such as restoration efforts that are again changing the face of marshes, reflecting a new appreciation for natural ecological services (Silliman et al. 2008). The perception of marshes in scientific circles as the quintessential mediators of human impacts is also changing. No longer can these systems be viewed as swampy wastelands, used to buffer and ameliorate human impacts along the coast. Instead, salt marshes now must be understood as highly valuable habitats whose worth is generated by a suite of ecosystem services that are critical in sustaining healthy lifestyles for coastal populations and the natural resources they depend on.

\section{Vulnerability of Salt Marshes to Human Impacts and Manipulation}

Salt marshes have long attracted human settlement; documented use of salt marshes for fishing and livestock grazing date to the Neolithic in the North and Wadden Seas (Knottnerus 2005, Meier 2004). The cradle of civilization and birthplace of agriculture is thought to be the Mesopotamian tidal marshes (Sanlaville 2002). In North America, colonists settled harbors with abundant salt marsh in the St. Lawrence, Massachusetts and Plymouth Bays, Bay of Fundy, and Long Island Sound (Hatvany 2003, Russell 1976, Sebold 1998) and used ancestral European agricultural practices to develop them (Butzer 2002).

Many features of salt marshes make them attractive to human populations. Salt marshes are among the most common and extensive intertidal habitats along many temperate coastlines (Chapman 1977) and have a low topography, often spanning only a few meters in elevation over thousands of meters of area. Across this simple topography rocks are rare, making salt marshes targets for conversion to arable land, coastal development, and harbors. Easy access by land and water has facilitated the exploitation of natural resources in these key coastal communities.

Owing to the coupling of salt marsh accretion with hydrodynamic processes, human manipulation of water resources and passages to establish permanent water supplies and navigable waterways has often had severe consequences, altering sediment supply and dramatically affecting plant distributions and biogeochemistry. For example, dikes and dams, engineered structures that restrict the flow of water to the marsh, deny the salt marsh sediment and ultimately lead to salt marsh subsidence (Portnoy \& Giblin 1997). To build land and protect the coast, people have exploited the connection between salt marsh vegetation, water flow, and sediment accretion by using salt marsh plants, many of which are excellent ecosystem engineers (sensu Jones et al. 1997), to modify water flow, trap sediments, and accrete the marsh foundation. People have often employed the most effective engineering plants for this purpose, whether native or non-native. Introduction of salt marsh species for coastal defense has led to large-scale invasions of many grasses, mostly from a single cosmopolitan genus, Spartina (Daehler \& Strong 1996).

The plants of salt marshes are readily harvested owing to the remarkable primary productivity of salt marshes (Mitsch \& Gosselink 2000) and their striking plant zonation, forming monocultures of robust natural plant products. Consequently, salt marsh plants have frequently been used for 
animal fodder, bedding, thatch, and commercial fiber products. Intense environmental stress from temperature fluctuations, high soil salinity, and low oxygen availability has limited salt marsh plant diversity to a handful of stress-tolerant, halophytic genera, a high proportion of which are cosmopolitan (Chapman 1977). Colonists of North America, recognizing the productive salt marsh plant genera of Old Europe, quickly exploited salt marsh resources in their new home (Butzer 2002).

Other impacts to salt marsh ecosystems have resulted from the proximity of human populations, initially drawn to salt marsh and coastal resources but later thriving in nonagrarian, industrialized economies. The open space of salt marshes near cities was first used as a dumping ground for sewage, trash, and other debris (Seasholes 2003, Tiner et al. 2002). As the final filter of runoff water entering an estuary, salt marshes near human development have long been subject to waterborne industrial and agricultural pollution, which can dramatically alter the species composition of normally nitrogen-limited salt marsh vegetation (Levine et al. 1998, Rozema et al. 2000). Large expanses of flat and open salt marsh lands near cities have been converted to port and industrial complexes, resulting in their permanent loss (Pinder \& Witherick 1990) and the disappearance of the ecosystem services they generated.

Salt marshes now face new regional and global challenges that correspond to the increasing scale of human impacts. Nutrient pollution and other large-scale human disturbances, such as the overharvesting of top predators and species introductions, have triggered consumer control of primary productivity in some marshes where consumers were not historically important. This rampant herbivory is of concern because salt marshes were once considered the paradigm of bottom-up control, and consumer control represents a major departure from this dogma. Consumers can transform marshes to exposed mudflats, a state that can be persistent (Bertness \& Silliman 2008). Additionally, global climate change is sure to affect salt marsh ecosystems, although the outcomes of specific climate effects remain uncertain. Accelerating sea level rise that is expected to accompany climate change will be a universal threat to these valuable coastal ecosystems and the services they provide.

\section{Ecosystem Services of Salt Marshes}

Ecosystem services are the benefits that humans derive from ecological systems and are generated directly from the processes that sustain ecosystems, or ecosystem functions, such as primary and secondary productivity, decomposition, and nutrient transformations (UNEP 2006). These services come in many forms-the natural products societies require; the regulation of climate, water, and disease cycles; the processing of nutrients and soils; and the importance of the environment for recreation. There is increasing interest in identifying and assessing the value of ecosystem services to make ecosystems more resilient to our impacts and provide for our needs, an integrated management practice termed ecosystem-based management. Salt marshes generate some of the highest and most valuable ecosystem services among natural ecosystems (Costanza et al. 1997, 2007; Levin et al. 2001) (Table 1), and today one of the primary arguments for protecting salt marshes is to preserve and increase the quality and quantity of these services.

On coastal margins and riverbanks, salt marshes act as natural sea barriers: Salt marsh grasses bind soils and prevent shoreline erosion, attenuating waves and limiting flooding of coastal cities and towns (King \& Lester 1995, Moeller et al. 1996). Salt marshes also serve as nitrogen sinks, filtering runoff water and diminishing nitrogen input to estuaries (Valiela \& Teal 1979). Left uncontrolled, excess nitrogen causes toxic algal blooms and marine dead zones. Salt marshes provide essential refuge habitat for young fish and crustaceans, provisioning coastal fisheries (Boesch \& Turner 1984) that account for $90 \%$ of the world's fish catch (UNEP 2006). Migratory waterfowl 
Table 1 Values of ecosystem services of tidal marshes

\begin{tabular}{l|l|c}
\hline Ecosystem service & \multicolumn{1}{|c|}{ Examples of human benefits } & $\begin{array}{c}\text { Average value } \\
\text { (Adj. 2007 } \mathbf{\$}^{\mathbf{a}} \mathbf{h a}^{\mathbf{- 1}} \text { year }^{-\mathbf{1}} \text { ) }\end{array}$ \\
\hline Disturbance regulation & Storm protection and shoreline protection & $\$ 2824$ \\
\hline Waste treatment & Nutrient removal and transformation & $\$ 9565$ \\
\hline Habitat/refugia & Fish and shrimp nurseries & $\$ 280$ \\
\hline Food production & Fishing, hunting, gathering, aquaculture & $\$ 421$ \\
\hline Raw materials & Fur trapping & $\$ 136$ \\
\hline Recreation & Hunting, fishing, birdwatching & $\$ 1171$ \\
\hline TOTAL & & $\$ \mathbf{1 4 , 3 9 7}$
\end{tabular}

${ }^{a}$ Dollar values were adjusted for inflation from original data, presented in 1994 dollars (Costanza et al. 1997). The adjustment was done with the U.S. Department of Labor Inflation Calculator, which uses the Consumer Price Index to correct values through time. Please see Costanza et al. (1997) for valuation methods and note that this valuation method is not universally accepted by economists, see Bockstael et al. (2000).

feed in salt marshes, where recreational hunters and birdwatchers follow their movements (UNEP 2006). As global climate change intensifies, the service of carbon storage performed by salt marshes gains importance, particularly at higher latitudes where carbon release by decomposition is slower and salt marshes are effective carbon sinks (Chmura et al. 2003).

Humans have long recognized that salt marshes generate these services and many others, but marshes have often been misused by managers seeking to exploit nonrenewable services. For instance, reclamation of salt marsh for upland uses provides a vital service to humans in added land, but the cost of reclamation is extraordinary if one accounts for the lost ecosystem services of natural marsh. The result is a net loss for society (Table 1). When managers try to maximize only one ecosystem service, poor decisions are made, such as the introduction of invasive species of Spartina for coastal protection, which has compromised the provisioning of natural Chinese salt marshes (An et al. 2007). Alternatives, opportunity costs, and maximization of value, including all ecosystem services combined, must now be incorporated into salt marsh management schemes.

\section{IMPACTS}

Large efforts have been made to evaluate and remediate human impacts on marshes. In this review, we evaluate and summarize multiple human threats to marshes in a historical context. The interpretation of the term threat is, of course, subjective. From different perspectives, changes in salt marshes can be seen as positive or negative, and the perception of many human impacts in salt marshes has changed over time. For example, what has in earlier eras been viewed as the improvement of wasteland (land reclamation) has later been characterized as habitat loss (land conversion).

We discuss human actions in salt marshes and their associated impacts, and we contextualize these impacts in terms of their effect on ecosystem services. For each general category of human action (resource exploitation and extraction, land conversion, species introductions, hydrologic alteration, pollution, changes in consumer control, and climate change), we first describe the human activity and its history, and then discuss impacts of the activity on plant and animal communities, marsh biogeochemistry, and surrounding habitats. Finally, we end with a discussion of restoration and management techniques that attempt to undo or compensate for previous human impacts in salt marshes. 


\section{Resource Exploitation and Extraction}

The most common use of salt marshes around the world has been as pasturelands for livestock (e.g., cattle, sheep, goats, and horses) (Knottnerus 2005), a practice that has not notably impacted ecosystem services, but that has in some cases made observable changes to species composition and animal populations. This practice is still common in China, Chile, and Europe, although it has become rare in Canada and the United States (Hatvany 2003, Sebold 1992). In the late 1800s along the St. Lawrence in Canada, marshland was valuable farmland. Marsh-holding farmers (including those with reclaimed marshland) supported $45 \%$ more livestock, on average, than non-marshholding farmers (Hatvany 2003). Spartina patens was considered highly nutritious fodder and was harvested annually in the United States and Canada-hence its common name, salt marsh hay (Sebold 1992). The products of marsh farms have often been considered to be of high quality and even delicacies; butter made from the milk of cows grazed on salt hay in the St. Lawrence Estuary enjoyed a gourmet boutique status in the late 1800s (Hatvany 2003), and salt marsh-fed lamb is still advertised as a French delicacy (LeJemtel Hostle 2004).

Beyond use as fodder, salt marsh plant products have been used as animal bedding, thatch (Phragmites australis, still used in England; Kiviat \& Hamilton 2001), rope (S. patens; Seasholes 2003, Sebold 1992) (Figure 1i), packing for pottery, metal and icehouse insulation (S. patens), and a nearly weedless mulch (S. patens, wrack, or Ulva; Sebold 1992). Native Americans used the reed $P$. australis for an astounding diversity of products including musical instruments, baskets, arrowshafts, and cigarette casings (Kiviat \& Hamilton 2001).

In the face of these impacts, salt marshes have proved to be surprisingly resilient. In the far north marsh communities of the Baltic, grazing favors halophytic plant species by allowing shortstatured halophytes to compete for light and by compacting the soil, which results in higher soil salinities (Dijkema 1990). Despite such notable effects on plant community composition, the continued productivity of grazed and harvested salt marsh vegetation demonstrates the resilience and high productivity of salt marshes. Turner (1987) found trampling by grazers to have more significant effects than biomass removal, and salt marsh sites were able to withstand intense grazing. Perhaps the seasonality of marsh plants at higher latitudes contributes to this resilience; mid-season removal of biomass does not seem to disrupt plant re-emergence and apparently does not result in the buildup of hypersalinities that would impede plant regrowth. The fact that many salt marsh plants reproduce clonally, with little seed-driven reproduction, is likely of key importance to plant resilience. Levin et al. (2002) suggested that salt marsh plants may have an evolutionary history that included grazing by now-extinct Pleistocene mammals.

Impacts of grazing on vegetation, however, can have ripple effects in salt marsh animal communities. Horse grazing can affect the use of marshes by birds and crabs, reducing the number of ground nesting birds, but positively affecting the abundance of bird and crab consumers by trimming away the grass canopy and exposing fish and invertebrate prey (Brewer et al. 1998). In the Netherlands, grazing of livestock in marshes affects plant species composition and reduces vegetation height, making the marshes more attractive to herbivorous geese (Bos et al. 2005). Grazing management techniques can have the same effect. In Argentina, salt marshes are burned to improve cattle forage, which reduces cordgrass height, plant species richness, and bird abundance (Isacch et al. 2004). There is no record of grazing impacts affecting neighboring habitats, although clearly impacts on transitory birds, fish, and invertebrates may spill over.

\section{Land Conversion}

The conversion of marshland to upland was historically undertaken for agricultural purposes, but in the past century it has mainly occurred for urban development. In some cases, human action 


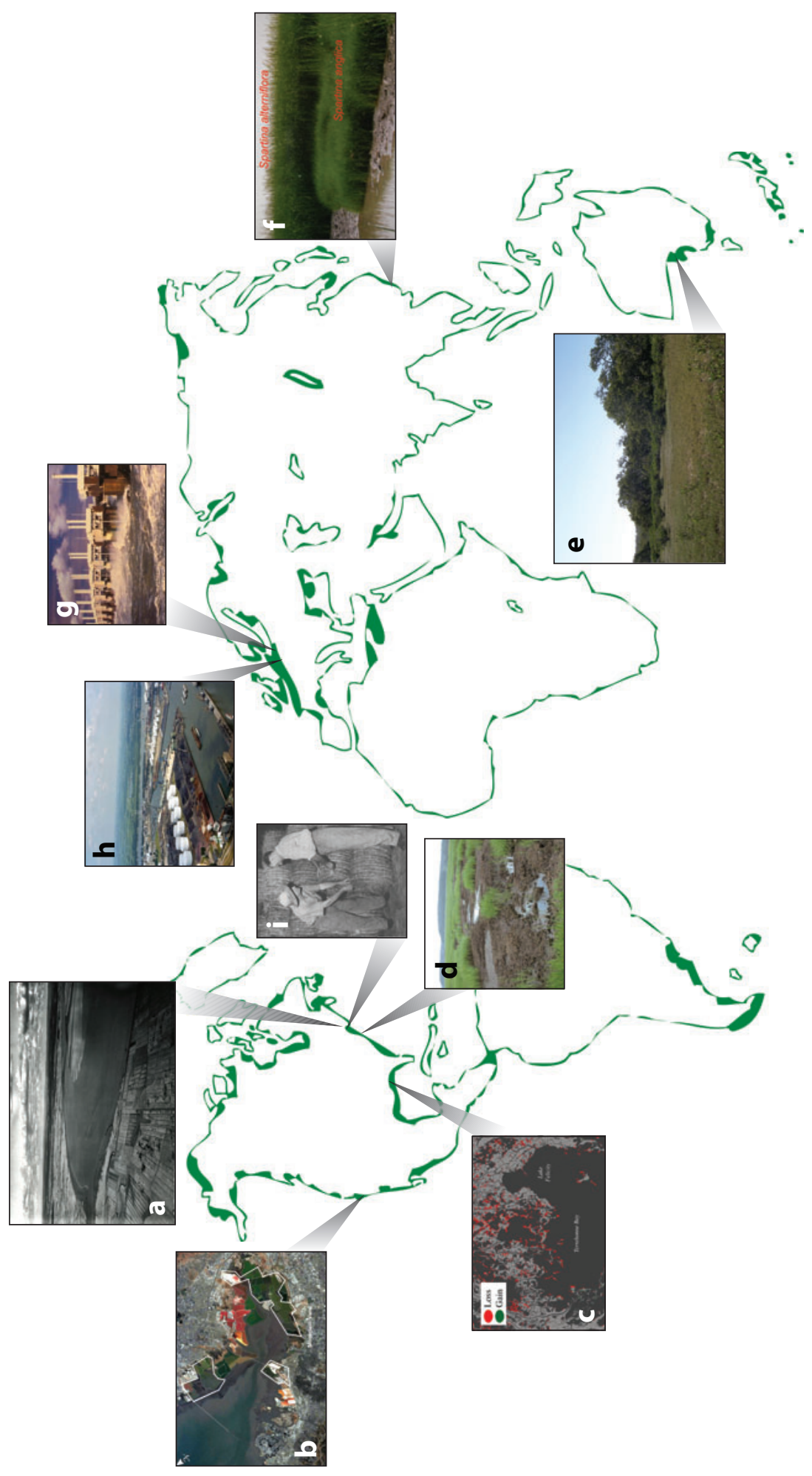

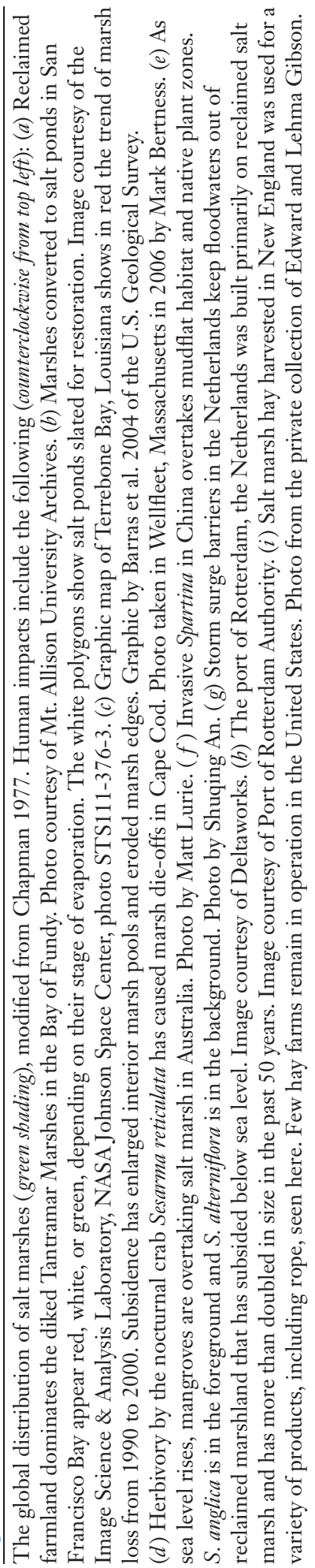


has inadvertently increased salt marsh area, as during the 1850s Gold Rush in California when upland erosion from hydraulic mining resulted in the formation of an estimated 7500 ha of new marsh in San Francisco Bay (Atwater et al. 1979). Deforestation of the eastern United States in the nineteenth and twentieth centuries had a similar effect on sediment supply and salt marsh accretion (Ward et al. 1998). Further investigation will likely show that marsh formation was enhanced wherever major deforestation occurred (Williams 2006, Yoshinobu 1998). However, overall humans have caused a net loss of salt marsh area; in San Francisco Bay losses exceed 200,000 ha (Atwater et al. 1979). In a study of 12 of the world's largest estuaries, Lotze et al. (2006) found a $67 \%$ loss of coastal wetlands during human history.

Agricultural transformations. The fertile soils of salt marshes were already being co-opted for upland agriculture by the eleventh century, when farmers in the Netherlands and France began building dikes for agricultural conversion and flood protection (Knottnerus 2005, Reise 2005), and the date may have been even earlier in China (Yoshinobu 1998). These reclamation practices were exported to North America by European colonists in the early 1600s (Butzer 2002) (Figure 1a). In the United States, farmers shifted from using natural marsh products to marsh reclamation when farming changed from a subsistence to market-oriented practice and it proved more profitable to convert salt marsh to upland for growing English hay (Sebold 1998).

Diking was also used as a land-building technology. In shallow estuaries with high sedimentation rates, salt marshes rapidly developed on the seaward side of dikes. As the marsh expanded, new dikes were added to continue the process, leaving a serial pattern of marsh succession (e.g., Doody 1992). Dijkema (1987) evaluated the extent of diking activities and concluded that since 1800 the Dutch Wadden Sea has experienced a salt marsh gain of 1500 ha on islands and net loss of 5000 ha on the mainland, for a nationwide net loss of $3500 \mathrm{ha}$. Another way to evaluate the impact of diking is by the area of reclaimed lands, because most were converted from marsh. By these estimates, reclaimed areas are astonishingly large (Table 2), amounting to 550,000 ha in the Dutch Wadden Sea (Powers \& Teeter 1922). In some places, diking practices have continued in recent years; Sun et al. (2003) discuss the immediate impacts of a dike installed in the Chianjiang Estuary in eastern China in 1998.

If the reclaimed marsh is not actively cultivated, the diking and accompanied drainage still have large ecological consequences, disrupting salinity gradients and causing an abrupt transition from halophytic vegetation to brackish and freshwater species, often P. australis or Typha angustifolia (Roman et al. 1984). This pattern stands in stark contrast to natural landscape-scale estuarine salinity gradients where plant species composition and dominance shift gradually (Crain et al.

Table 2 Agricultural/diking reclamations

\begin{tabular}{l|c|c|c}
\hline Location $^{\mathbf{a}}$ & Area of reclaimed land & Year of last reported diking activity $^{\mathbf{b}}$ & Reference $^{\text {Bay of Fundy, Canada }}$ \\
\hline Baware Bay, United States & $32,000 \mathrm{ha}$ & - & Ganong 1903 $^{\text {ha }}$ \\
\hline Delawat Britain & $5284 \mathrm{ha}^{\mathrm{c}}$ & present & Sebold 1992 \\
\hline St. Lawrence Estuary, Canada & $1000 \mathrm{ha}$ & 1980 & Doody 1992 \\
\hline Wadden Sea, Netherlands & $550,000 \mathrm{ha}$ & 1981 & $\begin{array}{c}\text { Reed \& Moisan 1971, } \\
\text { Hatvany 2003 }\end{array}$ \\
\hline
\end{tabular}

${ }^{a}$ Nesbit (1885) details salt marsh reclamation activities in the entire United States by county, but owing to the age of the source and unknown present status of reclaimed lands, these statistics are not reported here.

${ }^{\mathrm{b}}$ The year of last reported activity is constrained by the publication year of the cited reference.

${ }^{\mathrm{c}} \mathrm{A}$ large restoration project is underway presently in Delaware Bay that will revert 1779 ha of diked marsh. 
2004, Odum 1988). Along the Dutch coast, brackish and fresh tidal marshes have been entirely eliminated (Reise 2005), and brackish habitat specialists, both plant and animal, have likely also been lost.

The biogeochemistry of salt marsh soils, naturally characterized by slow sulfate reduction decomposition and tidal flushing of metabolic toxins (Mendelssohn \& Morris 1999), is also altered by diking. Behind dikes, toxic sulfides accumulate in undrained areas. Diked and drained marsh soils become acidified and organic matter is more rapidly oxidized (Portnoy 1999). Sediment starvation and increased decomposition behind dikes causes subsidence of the marsh surface (Portnoy \& Giblin 1997).

The landward effects of dikes are visually striking, but diking effects extend seaward as well. Hood (2004) found that the surface area of tidal channels is reduced seaward of dikes and channels become straighter and wider. Doody (1992) and Reise (2005) describe intertidal squeeze, where sediment supply outside of dikes cannot maintain all intertidal habitats and salt marshes begin to replace seaward tidal flats and seagrass beds. In the Wadden Sea, where diking impacts have been extreme, loss of intertidal habitats has endangered and extirpated many marine species (Lotze 2005).

Salt production. A precious commodity throughout history, salt has long been extracted in massive quantities from salt marshes, and production and extraction processes have converted large areas of marshland. Commercial salt extraction in marshes dates back at least to the seventh century in the Netherlands and France (Knottnerus 2005). In arid southern Europe, salt production required conversion of salt marsh to solar evaporative salt ponds, some of which still operate, producing the famous fleur de sel in France (Laszlo 2001). In cooler northern Europe, salt was collected from salt marshes by peat harvest and burning (Bridbury 1955). For this purpose, marshes were drained with the aid of the iconic Dutch windmill (Hoeksema 2007). At the same site, livestock were grazed on marsh grass, and after slaughter, marsh salt was used to preserve meat that was loaded onto ships and sent to market.

As with cultivated reclaimed land, the plant and animal communities from marshes converted to salt works have been lost, and dikes built to maintain salt works have led to subsidence, exacerbated by removal of peat for salt harvest. On the Dutch coast, peat removal for salt production and combustion fuel contributed to subsidence of the land by 2-5 $\mathrm{m}$ behind dikes (Hoeksema 2007). Many former salt works were eventually flooded and are now coastal inlets (Bridbury 1955, Reise 2005). Approximately two thirds of the Netherlands is at or below sea level today and would be flooded without coastal engineering (Figure 1 $\mathbf{g}$ ).

More recently, conversion of marsh for evaporative salt ponds has had a large impact on the California coast (Figure 1b). In the early twentieth century, 120 ha in Monterey Bay (Van Dyke \& Wasson 2005) and 507 ha near San Diego (Zedler 1996) were converted to salt works. The Monterey Bay Salt Works has since dissolved and the levees failed, but the marsh remains severely degraded. Currently, western Australia is the world's leading producer of solar salt, and salt marsh, tidal flat, and mangrove areas are still being converted (Adam 2002).

Urban and industrial land use. Many areas that were formerly diked farmland or salt works were later irreversibly transformed into urban, residential, and industrial land. Large coastal cities such as Boston, San Francisco, Amsterdam, Rotterdam, Venice, and Tokyo expanded onto former salt marshes. Marsh loss due to urban and industrial conversion exploded after 1950, when industrial and port complexes expanded to accommodate supertankers, oil and gas storage, and raw material processing (Pinder \& Witherick 1990). For example, 7000 ha of coastal marsh and lagoon were lost during port expansion in Marseilles, France between 1965 and 1975 (Pinder \& Witherick 1990). 
As U.S. cities grew, salt marshes were used for waste disposal and later filled. In the New York City area, the Hackensack Meadowlands were used as a landfill and ultimately $72 \%$ (nearly 2000 ha) was converted to a sports complex, industrial land, transportation and communication facilities, and open water between 1966 and 1985 (Tiner et al. 2002). In New York and Boston, major airports were built on filled marshlands. In Greater Boston, $81 \%$ of salt marsh coverage in 1777 has been lost, and marsh loss across all New England (estimated at 39\% loss since the early 1800s) is highly correlated to urban expansion (Bromberg \& Bertness 2005). Since approximately 1970 , urban and industrial reclamation of coastal marsh has slowed in western countries, where environmental advocates have championed wetland conservation and helped promote legislation that protects marshes, in part by arguing for the merits of ecosystem services provided by healthy marshes. However, in Asia, where population growth and land demand on the coast are intense, reclamation of salt marshes continues. In Hong Kong alone, Pinder \& Witherick (1990) estimate that 2400 ha of wetlands have been reclaimed since 1973. Wherever salt marsh loss continues, whether for industrial growth (e.g., Rotterdam; Figure 1 $b$ ), livestock farming (e.g., China), or salt production (e.g., Australia), salt marsh plant and animal communities and ecosystem services to coastal populations are compromised.

\section{Species Introductions and Invasive Species}

With high productivity, tolerance of waterlogged and anoxic conditions, and peat-building capabilities, introduced salt marsh plants have been popular additions to coastal areas. Nearly all intertidal Spartina species have been introduced in one place or another (Daehler \& Strong 1996), beginning with the introduction of the hybrid species Spartina anglica (the result of chromosome doubling in $S$. townsendii, a cross of S. alterniflora $\times$ maritima) in English salt marshes in 1870 (Ranwell 1967, Raybould et al. 1991). S. anglica rapidly colonizes mudflats and was planted for coastal engineering and defense (Ranwell 1967). S. anglica has displaced native Zostera marina on British coasts, Puccinellia maritima on Dutch coasts (Daehler \& Strong 1996), and mudflat, seagrass, mangrove, and marsh habitats in southern Australia (Kriwoken \& Hedge 2000). Introduced $S$. anglica has not been as aggressive in Chinese marshes, but $S$. alterniflora, also non-native to China, outcompetes native P. australis and Scirpus mariqueter (An et al. 2007) (Figure 1f ). In Mediterranean salt marshes, $S$. densiflora, native to the arid marshes of South America, is displacing native plants at all intertidal elevations (Nieva et al. 2005).

An aggressive, European P. australis haplotype has increased in abundance in North American marshes over the past century, outcompeting native plants (Minchinton et al. 2006, Orson 1999, Saltonstall 2002). P. australis responds positively to low salinity, high nutrient, and disturbed conditions (Chambers et al. 1999, Minchinton \& Bertness 2003), and it has been especially successful at overtaking human-dominated and low salinity marshes (Bertness et al. 2002, Silliman \& Bertness 2004). In general, nutrient enrichment favors invaders over native plant species in salt marshes (P. australis, Bertness et al. 2002; S. alterniflora $\times$ foliosa, Tyler et al. 2007), such that species invasions are more likely in marshes impacted by nutrient pollution.

Salt cedars, Tamarix spp., have recently invaded U.S. Pacific coast salt marshes (Whitcraft et al. 2007). The trees are salt tolerant and notably disrupt water cycling in riparian wetlands (Zedler \& Kercher 2004). In salt marshes, Tamarix invasion converts succulent plant communities less than $1 \mathrm{~m}$ in stature into woody-dominated communities with a 3-m canopy (Whitcraft et al. 2007).

These plant invasions significantly affect salt marsh animal communities. P. australis reduces aquatic habitat quality by infilling small streams and ponds and raising the marsh platform, and it is less palatable to animal consumers than other marsh plants (Zedler \& Kercher 2004). 
Weis \& Weis (2003) found that invasive P. australis stands had reduced epifaunal and mummichog densities. Reduced biodiversity of invertebrate species is associated with S. alterniflora invasion in China (An et al. 2007) and with S. alterniflora $\times$ foliosa invasion in California (Brusati \& Grosholz 2006). Where S. alterniflora $\times$ foliosa has invaded mudflats in California, effects of the grass on the physiochemical and hydrodynamic environment, as well as detritus quality and availability, have greatly disrupted trophic structure (Levin et al. 2006, Neira et al. 2006).

Many non-native animals were introduced unintentionally to salt marshes via ballast water disposal by ships. Similar to plant invasions, invasive animals have had powerful effects on both plant and animal communities, particularly in the case of exotic ecosystem engineers. Musculista senhousia, an exotic mussel to the Pacific coast of the United States, colonizes marshes and mudflats and creates hard substrate in previously soft sediment environments. The structural engineering of $M$. senhousia changes invertebrate communities, with enhanced densities of some species and diminished densities of native clams (Crooks 2001). The burrowing isopod Sphaeroma quoyanum was also unintentionally introduced to the U.S. Pacific coast, where its intense burrowing causes erosion at the marsh edge. Talley et al. (2001) estimated that in San Francisco Bay the marsh edge has been pushed back dozens of meters by $S$. quoyanum burrowing, making the invasive isopod a significant cause of marsh loss. Nutria, Myocaster coypus, introduced to the U.S. Gulf coast for fur farming, also contribute to marsh loss. The burrowing and foraging activities of this rodent depress soil accretion processes, ultimately leading to submergence of marshes with low sediment supply (Ford \& Grace 1998).

Engineering capacity has been linked to the transformational impact of invasive species in their non-native ranges for both plants and animals (Brusati \& Grosholz 2006, Crooks 2002). Invaders that alter the physical structure of the marsh environment, such as S. alterniflora, P. australis, and M. senhousia, have predictably strong effects on infaunal organisms (Brusati \& Grosholz 2006, Crooks \& Khim 1999, Neira et al. 2006, Zedler \& Kercher 2004).

\section{Hydrologic Alteration}

Salt marsh ecology is tied to hydrology in many ways. Freshwater runoff, groundwater inputs, and tidal flooding are important for sediment and nutrient delivery and plant water supply. Tidal inundation and flushing govern a fluctuating salinity and oxygen regime that is a critical determinant of plant productivity (Mendelssohn \& Morris 1999) and microbial production of sulfide and methane (Bartlett et al. 1987, Magenheimer et al. 1996). Human disruption of natural hydrologic patterns has affected natural biogeochemical cycling and plant communities.

Ditching. Salt marsh farmers often altered their land with shovel-dug drainage ditches, which increased the production of salt marsh hay (Sebold 1998). The invention in the 1800s of doublebladed saws and in the early 1900s of ditch-digging machines sped ditch construction (Sebold 1998). Beginning in 1904, intensive ditching was employed for mosquito control in the eastern United States (Smith 1904). Ditches control mosquito populations by draining off pooled waters where mosquito larvae develop and by allowing fish to feed on mosquito prey during high tides. Many large ditching projects were accomplished by work relief programs during the Great Depression (Stearns \& MacCreary 1936). During this period, many marshes were extensively ditched in parallel grid patterns, even in low marsh areas that were never suitable mosquito habitat (Provost 1977). Greater than $90 \%$ of all salt marshes in the U.S. northeast are ditched (Bourn \& Cottam 1950, Crain et al. in press). Southeastern U.S. and California sites have been heavily ditched in more recent decades (e.g., Resh 2001). A similar technique, runnelling, has been applied in Australia (Hulsman et al. 1989). 
The immediate effect of ditches is to create more tidal aquatic habitat at the expense of tidal terrestrial habitat. Ditches ameliorate waterlogging stress in the high marsh, with peat drainage up to $5 \mathrm{~m}$ away from ditches (Crain et al. in press, Daigh et al. 1938). By increasing tidal flushing frequency, ditches ameliorate anoxic stress and increase plant productivity near ditch banks (Shisler \& Jobbins 1977). Ditches have caused shifts in salt marsh vegetation that favor high marsh species, which are better belowground competitors when anoxic and saline stresses are reduced (Bertness \& Ellison 1987). In response to ditching in one Delaware marsh, S. alterniflora gave way to high marsh S. patens and the woody shrubs Iva frutescens and Baccharis halimifolia, often found on well-drained soils (Bourn \& Cottam 1950). Ewanchuk \& Bertness (2004) hypothesized that the absence of waterlogged forb panne communities in southern New England salt marshes is a result of intensive ditching.

Animal communities have had mixed responses to ditching; subtidal and intertidal animals such as fiddler crabs and fish are generally positively affected by the increase in habitat area and access to prey (Lesser et al. 1976, Valiela et al. 1977), and semiaquatic organisms such as dragonflies and water beetles are negatively affected by the loss of habitat and increase in predators (Bourn \& Cottam 1950, Resh 2001), although other studies show invertebrates are unaffected by ditching (Clarke et al. 1984).

Ecosystem-wide impacts of ditching on biogeochemical cycles and marsh accretion processes have not been thoroughly explored. Intensive ditching affects hydrology at a landscape level, altering channel formation and simplifying drainage networks (C.C. Bohlen, unpublished data). Ditched marshes also tend to have fewer ponds than unditched marshes (Adamowicz \& Roman 2005; C.C. Bohlen, unpublished data). Ditching may drain existing ponds, but the intentional deposition of spoil, or ditch wastes, in pools during ditch construction (Sebold 1998) also accounts for differences in pool area. Many have suggested that decreased use of ditched marshes by birds is due to the loss of these ponds (e.g., Clarke et al. 1984). Bird conservation groups have been some of the biggest proponents for alternative mosquito control techniques and ditch restorations (ditch plugging; Adamowicz \& Roman 2002).

Tidal restriction. Tidal restrictions limit tidal influence on upriver marsh areas. Restrictions occur under roads and railway crossings where culverts do not permit full tidal exchange, and are often exacerbated by tide gates. Berms or dikes restrict sheet flow across marshes (Buchsbaum 2001). Tidal mills and dams block tidal and freshwater drainage for reservoir creation. Crain et al. (2008) investigated the spatial extent of tidal restrictions in Maine salt marshes and found that in 3193 ha of tidal marsh, 57 restrictions affected 903 ha (28\%) of upriver tidal marsh. Moreover, 33 additional restrictions occurred at an abrupt transition from fresh to tidal marsh, underscoring the hidden impacts of head of tide restrictions on fresh tidal and brackish marshes. Restrictions are likely more common in more developed areas.

Tidal restrictions limit marine influence upriver, and impounded marshes become fresher and receive less input of inorganic sediments. Complete restriction converts impounded marsh to freshwater wetland, resulting in vegetation shifts from halophytic to glycophytic species, often including P. australis (Roman et al. 1984). In some cases, tidal restrictions have negatively impacted fish, as evidenced by a positive response of fish to restriction removal (e.g., Roman et al. 2002), although in other instances, no change was observed (e.g., Raposa et al. 2003). Tidal restriction greatly disrupts biogeochemical cycling. The impacts of tidal restriction lead to whole marsh subsidence in similar ways to the dikes described above, endangering wetland fauna (Soukup \& Portnoy 1986) and complicating restoration efforts (Portnoy 1999). 


\section{Pollution and Eutrophication}

Metal pollution. Salt marshes are depositional environments for suspended particulate matter and associated nutrients and metals (Nixon 1980). This process occurs naturally through geochemical weathering, but in close proximity to urban and industrial areas, anthropogenic levels have eclipsed natural inputs. Leendertse et al. (1996) found that sediments and vegetation in experimental salt marshes absorbed and transformed 30-65\% of deposited metals and concluded that salt marshes are sinks for metal contamination except during major erosion events. In an extreme example, in the historical mining area of Mar Menor, Spain, mean salt marsh sediment concentrations of $\mathrm{Cu}\left(>190 \mathrm{mg} \mathrm{kg}^{-1}\right), \mathrm{Pb}\left(8016 \pm 4077 \mathrm{mg} \mathrm{kg}^{-1}\right), \mathrm{Mn}\left(>2000 \mathrm{mg} \mathrm{kg}^{-1}\right)$, and $\mathrm{Zn}\left(6944 \pm 8280 \mathrm{mg} \mathrm{kg}^{-1}\right)$ exceeded European environmental and health criteria (Álvarez-Rogel et al. 2004).

In anoxic marine soils, free metal ions are precipitated as metal sulfides of low solubility, making deeper sediments of salt marshes stable repositories for pollutants in the absence of bioturbation or other oxidation of soils (Weis \& Weis 2004, Williams et al. 1994). The ability of marsh plant species to oxygenate the rhizosphere locally mobilizes metals, increasing bioavailability and uptake (Weis \& Weis 2004). There has been widespread interest in salt marsh plants as bioindicators and phytoremediators of pollutants. The effects of most environmental contaminants on salt marsh plants is beyond the scope of this review, but we summarize some important findings below.

Heavy metal uptake has rarely been found to have detrimental effects on plant growth or fitness (Giblin et al. 1980, Suntornvongsagul et al. 2007), although at the physiological level, it inhibits photosynthetic activity (Weis \& Weis 2004). The adaptations of halophytes for dealing with salt stress, such as cellular compartmentalization of solutes and excretion through salt glands, may allow for higher tolerance of metals (Williams et al. 1994, Windham et al. 2001). Several scientists, noting the capacity of $P$. australis to take up and store belowground a variety of metals, have recommended $P$. australis as a phytoremediator of $\mathrm{Hg}, \mathrm{Mg}$, and $\mathrm{Cr}$ contamination (Weis \& Weis 2004, Windham et al. 2001).

Though salt marsh plants have proved resistant to metal pollution, there is concern that resuspended metals pollute marine systems and that plant translocation of sediment-bound metals introduces contaminants into estuarine food webs. For example, Giblin et al. (1980) found that metals in S. alterniflora detritus were taken up by fiddler crabs, and metals are often found concentrated in bivalves near contaminated sites (Conesa \& Jiménez-Cárceles 2007, Leendertse et al. 1996). It is not clear if the concentrations of toxins in marine animals affect their fitness or survival.

Eutrophication. Like metals, nutrients are taken up and transformed by salt marsh sediments and plants, and salt marshes can act as long-term nutrient sinks (Valiela \& Teal 1979). Most salt marsh plants are nitrogen limited under natural conditions, and relief of nitrogen limitation results in an increase in aboveground plant height and biomass, often accompanied by a reduction in belowground biomass (Jefferies \& Perkins 1977, Kiehl et al. 1997, Valiela et al. 1976).

An abundance of nutrients alters competitive hierarchies of salt marsh plant species, resulting in restructured plant zonation (Levine et al. 1998). In New England salt marshes, extreme nutrient release causes a landward shift in S. alterniflora and a seaward shift in P. australis, such that zonal dominants at intermediate elevations can be entirely outcompeted (Bertness et al. 2002). Bertness et al. (2002) identified nutrient-rich runoff from human development as a proximate cause for $P$. australis invasion. Removal of upland forest for upland development allows more nitrogenladen freshwater to reach the marsh, conditions that favor P. australis growth (Silliman \& Bertness 2004). In the Wadden Sea, long-term vegetation change in salt marshes has also been attributed 
to eutrophication. There, the high marsh grass Elymus athericus increases at the expense of Festuca rubra in eutrophied marshes (Rozema et al. 2000).

Additional evidence of the ecological impacts of eutrophication comes from a catchment-scale experimental addition of nitrate and phosphate, designed specifically to examine ecosystem-level linkages and interactions between nutrient enrichment, biological composition, and biogeochemical cycling (Deegan et al. 2007). After two years of low-level nutrient addition $\left(30 \mathrm{~g} \mathrm{~N} / \mathrm{m}^{-2} / \mathrm{yr}^{-1}\right.$ over $60,000 \mathrm{~m}^{2} /$ treatment), consistent increases in aboveground biomass in S. alterniflora and possibly in $S$. patens have been observed. Nutrient enrichment also seems to have triggered topdown control of microalgae by killifish, which do not control algal biomass in nutrient-limited conditions (Deegan et al. 2007). Though this result might seem surprising, increases in consumer control in response to anthropogenic triggers have become increasingly common.

\section{Changes in Consumer Control}

Although the impacts discussed above stem directly from human action, some of the most important contemporary human impacts in salt marshes are only indirectly connected to human activities. In many ways, these indirect impacts are much more dangerous because we lack the ability, as yet, to directly predict or control them.

Historically, salt marshes were thought to be controlled exclusively by physical forces such as temperature, salinity, and nutrients. This paradigm grew from work by Eugene Odum (1971) and John Teal (1962) on Sapelo Island, Georgia that stressed the dominant role of physical factors in regulating ecosystem productivity and structure. The importance of consumers, although not tested experimentally, was largely disregarded and the dogma that herbivores are unimportant became entrenched in the conceptual understanding of coastal wetlands (Nixon 1982, Smalley 1960). There is mounting evidence, however, that human disturbances are triggering consumer control in salt marshes, often with catastrophic consequences (Bertness \& Silliman 2008).

The first strong evidence that human disturbance was turning on consumer pressure came from sub-Arctic Canada (Jefferies 1997). By the 1980s, the snow geese that annually migrated to Hudson Bay had switched from feeding in disappearing temperate zone wetlands to feeding in heavily fertilized agricultural fields. Consequently, snow geese populations nearly tripled in a decade, leading to runaway consumption and the denuding of extensive areas of Arctic marshes (currently $>37,000$ ha in southern Hudson Bay alone). This collapse was driven by intensive goose grubbing of plant roots that led to low plant cover and hypersaline, anoxic soil conditions. This soil stress created a negative feedback loop as adjacent vegetation died, soil salinity increased, and plants that recruited into newly denuded areas died from osmotic stress, preventing recovery. These cascading events, leading to system collapse, were initiated by the luxuriant use of artificial nitrogen fertilizer in the temperate zone.

Similar marsh die-offs, occurring for nearly two decades on the southeastern and Gulf coasts of the United States, have impacted more than 250,000 ha and received considerable media and scientific attention. Until recently, these die-offs were attributed solely to harsh physical conditions killing marsh plants. Simple field experiments, however, have revealed that high densities of the marsh snail Littoraria irrorata can entirely denude stands of marsh cordgrass ( $>2.5 \mathrm{~m}$ tall) in less than a growing season by facilitating lethal fungal infection in vertical grazing scars on leaf surfaces (Silliman \& Bertness 2002, Silliman \& Newell 2003, Silliman \& Zieman 2001). Historically, snail densities were largely controlled by predators, such as blue crabs and terrapins, which have been overharvested and now suffer from diseases and other maladies associated with small population size. This release of top-down pressure has potentially led to increased snail densities (Silliman \& Bertness 2002). Compounding increased consumer densities, drought stress, ostensibly a product 

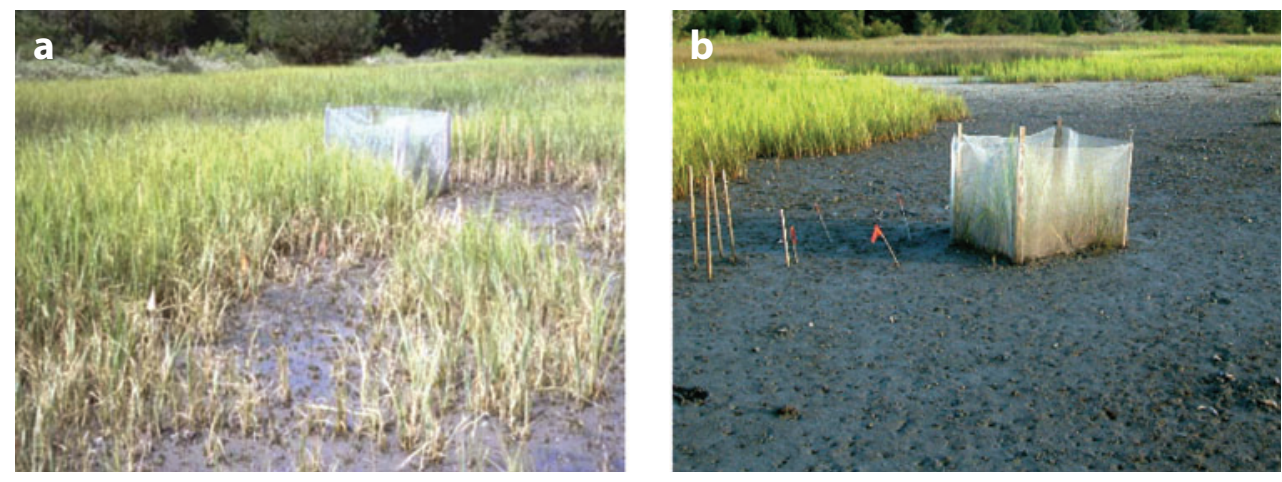

Figure 2

(a) Snail exclusion cage at the edge of a Georgia die-off in 2003. (b) The same cage three months later after snail grazing had expanded the patch.

of human-driven climate change, has elevated soil salinities throughout southeastern marshes and increased the vulnerability of S. alterniflora to consumer control by snails (Silliman et al. 2005). Simultaneous sublethal drought and high grazer density is often lethal to the foundation marsh grasses, reducing the services salt marshes provide. When physical and biological stressors act synergistically to kill marsh grasses, exposed mudflats emerge and waves of snails propel cascading vegetation loss (Figure 2).

More recently discovered examples of consumer control regulating plant biomass in marshes suggest a general trend. On the Atlantic coast of South America, salt marshes are dominated by extraordinarily high densities of the burrowing shore crab Chasmagnathus granulata, a voracious herbivore of the marsh grass $S$. densiflora (up to 60 individuals $/ \mathrm{m}^{2}$ with burrows covering up to $40 \%$ of the surface) (Bortolus \& Iribarne 1999). Recent crab removal experiments have revealed that bare areas, commonly making up half of the marsh habitat, are created and maintained by crab herbivory (Alberti et al. 2007, Alberti et al. 2008) (Figure 3). We suspect that the high densities of Chasmagnathus are at least in part due to the overfishing of predators. On the Atlantic coast of North America, the primary production of pristine marshes is controlled by nitrogen availability, but nitrogen additions trigger insect herbivory and suppress primary production by nearly $60 \%$. Insect herbivores are already suppressing the primary production of human disturbed salt marshes in Narragansett Bay by nearly 40\% (Bertness et al. 2008).

Most recently, reports of extensive die-offs of New England salt marshes on Cape Cod have received considerable media attention, but research has not addressed their cause. Not surprisingly, physical processes have been suspected to be causal, but current studies suggest that herbivory by a common nocturnal crab, Sesarma reticulatum, is playing a major role. Sesarma herbivory has already denuded up to $90 \%$ of creek banks in more than $70 \%$ of outer Cape Cod salt marshes (C. Holdredge, M. Bertness \& A.H. Altieri, manuscript submitted). Release from predation appears to be triggering elevated Sesarma densities and prompting these die-offs (Figure 1 $\mathbf{d}$ ).

Invasive herbivores have also contributed to increased consumer control in salt marshes. On the southeastern and Gulf coasts of the United States, introduced nutria have led to consumer control of marsh vegetation (Gough \& Grace 1998).

Together, these examples indicate that human impacts that alter animal populations in salt marshes, such as nitrogen pollution, overharvesting of top predators, climate change, and exotic consumer invasions, can have cascading effects on ecosystems once thought to be under little or no consumer control. 


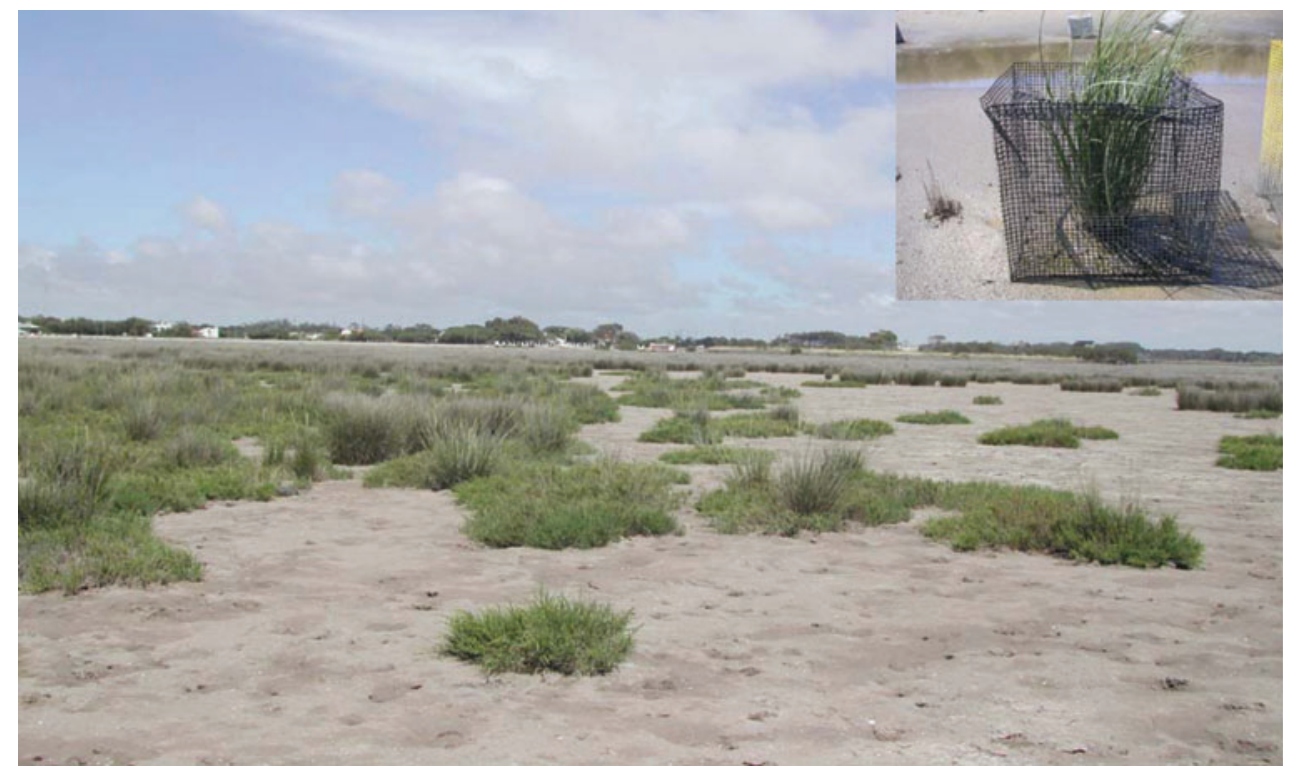

Figure 3

Bare zone in the Mar Chiquita lagoon salt marsh in central Argentina. These bare zones are maintained by herbivory by the crab Chasmagnatbus granulata. When Spartina densiflora is transplanted into the bare zone it is eaten, unless it is caged and protected from crabs (inset).

\section{Climate Change}

Like changes in consumer control, climate change is a global and accidental force caused by human activity. Great uncertainty remains regarding the impacts the shifting climate will have on salt marshes, and the ultimate response of marsh ecosystems could affect the degree of climate change, potentially moderating or exacerbating warming. This feedback is due to the exceptional capacity of salt marshes to act as carbon sinks. Chmura et al. (2003) estimated that on an area basis, tidal wetlands (salt marshes and mangroves) sequester 10 times more carbon than peatlands (210 $\mathrm{g} \mathrm{CO}_{2} \mathrm{~m}^{-2}$ year $^{-1}$ versus $20-30 \mathrm{~g} \mathrm{CO}_{2} \mathrm{~m}^{-2}$ year $^{-1}$ in peatlands), in part because saline wetlands emit less methane and $\mathrm{CO}_{2}$ than freshwater wetlands. Climate-related changes to the carbon cycle are likely to alter the sequestration service provided by salt marshes, as well as affect long-term rates of salt marsh accretion and the ability of marshes to keep pace with sea level rise in ways that are still unclear.

$\mathrm{CO}_{2}$. Anthropogenic increases in atmospheric $\mathrm{CO}_{2}$, the major driver of climate change, will affect salt marsh plant species differentially. Due to differences in their treatment of $\mathrm{CO}_{2}$ at the cellular level, $\mathrm{C}_{3}$ plants are expected to respond more positively to $\mathrm{CO}_{2}$ increases than $\mathrm{C}_{4}$ plants, a hypothesis that has been supported by field experiments that manipulate $\mathrm{CO}_{2}$ concentrations (Ainsworth \& Long 2005). In a brackish tidal marsh in the Chesapeake Bay, the experimental doubling of $\mathrm{CO}_{2}$ concentrations elicited a sustained biomass increase in Scirpus olneyi, a $\mathrm{C}_{3}$ sedge, in control plots over 18 years (Erickson et al. 2007).

Salt marshes dominated by $\mathrm{C}_{4}$ grasses, such as Spartina and Phragmites spp., may respond differently. In the Chesapeake Bay study, the $\mathrm{C}_{4}$ grasses $S$. patens and Distichlis spicata did not grow more rapidly under elevated $\mathrm{CO}_{2}$ conditions. Growth chamber studies have also found no growth response in European $\mathrm{C}_{4}$ salt marsh species reared in elevated $\mathrm{CO}_{2}$ conditions (Lenssen et al. 
1993, Rozema et al. 1991). This evidence suggests that the response of salt marshes to elevated $\mathrm{CO}_{2}$ will be dependent on plant composition and that higher concentrations of $\mathrm{CO}_{2}$ will favor compositional shifts toward $\mathrm{C}_{3}$ plants, as $\mathrm{C}_{4}$ plants are gradually outproduced and outcompeted.

Temperature change. Climate change could alter the geographical distribution of salt marshes, which currently span temperate and arctic latitudes from $30^{\circ}$ to $80^{\circ}$ (Chapman 1977) (Figure 1), and salt marsh plant species and could also affect ecosystem productivity. The productivity of salt marshes is tied to latitude and climate; greater productivity occurs at lower latitudes (Turner 1976). Although this relationship exists, it has not been well characterized. Experiments are underway to determine the connection between temperature and marsh productivity.

Storm intensity. With climate change, the intensity of hurricanes is expected to increase (IPCC 2007). As the first line of coastal defense, salt marshes are greatly affected by storms. In the longterm, the magnitude of the ecological disturbance caused by storms is less in marshes than in terrestrial habitats (Michener et al. 1997). Salt marshes were the only habitat on Cape Cod with little reported damage from Hurricane Bob in 1991, probably because, unlike other upland salt marsh organisms, species are highly adapted to salt stress and inundation (Valiela et al. 1998). Coastal storms do, however, have short-lived effects in salt marsh communities. Storm surges push salt water up estuarine gradients, raising salinities in brackish and freshwater tidal marshes and temporarily shifting plant distributions. Floodwaters can drown salt marsh mammals and ground-nesting birds, causing brief and localized population declines (Michener et al. 1997).

Storm-delivered sediments are an essential part of the sediment budgets of many marshes (Conner et al. 1989, Turner et al. 2006), but the contribution of storm sediments to total accretion varies greatly; at some sites, especially in marshes already degraded by human impacts, storms can cause a net loss in elevation (Cahoon 2006). Cahoon (2006) found varying effects of storms on marsh elevation, including increases due to sediment deposition and stimulation of root growth and decreases due to erosion and compaction of soils. Increases in storm intensity will likely increase interannual and intermarsh variability in sedimentation rates.

Sea level rise. Historically, sea level rise has been integral to sediment delivery and geologic development of the salt marsh. As rates of sea level rise have increased, rates of salt marsh accretion have also hastened, sometimes exceeding sea level rise rates over the short term (Nixon 1980, Roman et al. 1997). However, as sea level rise continues to accelerate, there is concern that the rate of sea level rise will outpace the rate of accretion and salt marshes will drown.

Sea level rise effects manifest in salt marshes in two different ways: 1) landward migration of salt marsh vegetation zones and submergence at lower elevations, and 2) interior ponding and marsh drowning.

The landward migration of low-marsh and high-marsh vegetation zones has been attributed to sea level rise in New England salt marshes. Donnelly \& Bertness (2001) observed a rapid landward expansion of S. alterniflora over the past 200 years, coincident with an acceleration in the rate of sea level rise. Warren \& Niering (1993) compared vegetation cover data and peat profiles from 1947 and 1987 and found an increase in forbs and stunted S. alterniflora and a decrease in S. patens and funcus gerardii in the high marsh. Because stunted S. alterniflora and salt marsh forbs generally occur in more waterlogged soil conditions, these results are also consistent with sea level rise. Sea level rise has eroded the seaward edge of European salt marshes (e.g., Day et al. 1998). Seaward habitats may replace salt marsh during landward migration; sea level rise is contributing to the replacement of salt marsh by mangroves in Australia (Rogers et al. 2005) (Figure 1e). Rising 
water levels are particularly worrisome because in many areas the response of plant communities is constrained by steep shorelines and human structures.

The high marsh may be particularly vulnerable to drowning. Productivity of low marsh S. alterniflora increases with inundation (to a point), leading Morris et al. (2002) to suggest that increases in accretion linked to plant productivity are a stabilizing mechanism that allows $S$. alterniflora marshes to respond to variation in sea level. However, in the high marsh, many plants are less productive when inundated and accrete more slowly, a feedback that can quickly transform high marsh into open water. In Chesapeake Bay and Mississippi River delta marshes, sea level rise has caused an increase in high marsh ponding (Barras et al. 2004, Kearney et al. 1988) (Figure 1c), although sediment starvation and hydrologic alteration have also contributed to the subsidence (Turner 1997, Ward et al. 1998).

Despite uncertainty about many of the potential effects of climate change on marshland, it seems clear that sea level rise will profoundly alter salt marshes by causing migrations of plant species and their associated fauna as well as marsh drowning.

\section{RESTORATION, CONSERVATION, AND MANAGEMENT}

After millennia of human exploitation of salt marsh resources and services, a new human impact has gained momentum in recent years: restoration. As policymakers and coastal dwellers have gained an appreciation for the natural ecosystem services of marshland, attempts have been made to prevent degradation and reverse historical changes. These efforts have taken many forms, and we discuss several of them, again in the context of human action and ecosystem services.

\section{Restoration to Preimpact or Reference Conditions}

One approach to restoration holds pristine conditions of salt marshes in the highest regard, with the expectation that many of the ecosystem services we depend on, such as carbon and nutrient sequestration, coastal defense, and wildlife habitat, are maximized in natural and healthy marshes. This is the most familiar concept of restoration, in which the aim is to replicate conditions in a nearby unimpacted marsh site (Neckles et al. 2002). This type of restoration includes invasive species eradications and removals of tidal restrictions.

In Delaware Bay, for example, the Public Service Enterprise Group (PSEG), a power utility, has begun restoring 4000 ha of degraded salt marsh to compensate for environmental impacts of the company's nuclear power generation. The PSEG project includes breaching formerly diked salt hay farms and removing invasive $P$. australis with herbicide to restore natural function and ecosystem services (Balletto et al. 2005). In California, more than 6000 ha of commercial salt ponds, formerly owned by Cargill Salt Company, are being restored to tidal marsh with the goal of increasing natural habitat in San Francisco Bay, in part to improve flood protection and water quality (Shoreline Study 2005).

In some places, created marshlands have been built to offset previous losses. Marsh is built with dredged material deposited in shallow subtidal areas, and sometimes plant regrowth is initiated with plantings (Posey et al. 1997). Although these created wetlands are meant to restore the full suite of ecosystem services of a natural marsh, debate continues about whether created marshes are functionally equivalent to natural marshes (Moy \& Levin 1991, Posey et al. 1997).

\section{Restoration to Maximize a Single Ecosystem Service}

Where salt marshes can prevent or remediate environmental damage through optimization of a single ecosystem service, restorations are designed for this purpose. 
Small wetlands next to airports, highways, industrial complexes, and landfills have been constructed and managed to intercept polluted runoff water. Contrary to other types of restorations, in these marshes $P$. australis is encouraged to grow for its ability to take up and transform nutrients and heavy metals (Shutes 2001). A transgenic line of S. alterniflora that can break down mercury has been developed for phytoremediation activities (Czakó et al. 2006). Phytoremediation marshes have been managed and constructed mainly at small scales, but large-scale application, or nitrogen farming, has been proposed as a solution to the agricultural pollution problem of the Mississippi River watershed (Hey 2002).

Many coastal managers desire to preserve or restore salt marshes for the express purpose of defense against sea level rise. Managed retreat, as this goal is known in England, reverts reclaimed land to intertidal marsh and mudflat by moving dikes or seawalls inland to create a more natural coastal flood buffer (Hazelden \& Boorman 2001). In 2002, approximately 200 ha of salt marsh in England were restored in experimental tests of managed retreat (Pethick 2002). The feasibility of large-scale application of managed retreat remains in question.

Although in some instances these single-service sites incidentally provide secondary benefits, such as recreational land or carbon storage, an integrated management approach to maximize all ecosystem services would better serve coastal populations. With a full suite of species and ecosystem functions, salt marshes will be better prepared to cope with the next indirect and unpredicted human impact.

\section{CONCLUSION}

The many ecosystem services, natural accessibility, and productivity of salt marshes have made them attractive ecosystems for exploitation and human use throughout history. Human impacts of resource exploitation, reclamation, coastal engineering, and pollution have altered so many marshes that the ecosystem services of the remaining degraded salt marshes are insufficient for many coastal populations. Management has sought to restore some services in many parts of the globe, but an integrated approach, with simultaneous consideration of all ecosystem services, is needed.

The current most pressing impacts in marshes are invasive species fundamentally altering salt marsh community structure, unexpected consumer effects ravaging marsh vegetation, and the relatively unexplored and multifaceted effects of climate change.

\section{FUTURE ISSUES}

1. Further work is needed to determine how and why shifts in regulating mechanisms of salt marshes are occurring worldwide and to identify the drivers.

2. Experiments must be used to test the relative importance of driving forces that can cause salt marsh degradation.

3. The effects of multiple stressors on salt marsh communities have rarely been examined, but when investigated, have had unexpected and synergistic consequences (e.g., eutrophication exacerbates species invasions, drought and overfishing make S. alterniflora more vulnerable to consumer effects). Salt marshes are experiencing simultaneous changes in climate and food web structure owing to direct and indirect effects of human activities. We recommend further multistressor experiments be undertaken in salt marsh communities.

4. We recommend multipriority management schemes (ecosystem-based management). 


\section{DISCLOSURE STATEMENT}

The authors are not aware of any biases that might be perceived as affecting the objectivity of this review.

\section{ACKNOWLEDGMENTS}

We thank all the individuals and organizations that allowed us to reprint photos and graphics. We would like to thank Benjamin Gedan and the editorial reviewer of the Annual Review of Marine Science for helpful edits and comments. This research is funded by a U.S. Environmental Protection Agency Science to Achieve Results (STAR) Graduate Fellowship to K.B.G. The Environmental Protection Agency (EPA) has not officially endorsed this publication and the views expressed herein may not reflect the views of the EPA.

\section{LITERATURE CITED}

Adam P. 2002. Saltmarshes in a time of change. Environ. Conserv. 29:39-61

Adamowicz SC, Roman CT. 2002. Initial Ecosystem Response of Salt Marshes to Ditch Plugging and Pool Creation: Experiments at Rachel Carson National Wildlife Refuge (Maine). Newington, NH: U.S. Fish and Wildlife Service, Region 5

Adamowicz SC, Roman CT. 2005. Salt marsh pools: a quantitative analysis of geomorphic and geographic features. Wetlands 25:279-88

Ainsworth EA, Long SP. 2005. What have we learned from 15 years of free-air $\mathrm{CO}_{2}$ enrichment (FACE)? A meta-analytic review of the responses of photosynthesis, canopy properties and plant production to rising $\mathrm{CO}_{2}$. New Phytol. 165:351-72

Alberti J, Escapa M, Daleo P, Iribarne O, Silliman BR, Bertness MD. 2007. Local and geographic variation in grazing intensity by herbivorous crabs in SW Atlantic salt marshes. Mar. Ecol. Prog. Ser. 349:235-43

Alberti J, Escapa M, Iribarne O, Silliman BR, Bertness MD. 2008. Crab herbivory regulates plant facilitative and competitive processes in Argentinean marshes. Ecology 89:155-64

Álvarez-Rogel J, Ramos Aparicio MJ, Delgado Iniesta MJ, Arnaldos Lozano R. 2004. Metals in soils and above-ground biomass of plants from a salt marsh polluted by mine wastes in the coast of the Mar Menor Lagoon, SE Spain. Fresenius Environ. Bull. 13:274

An SQ, Gu BH, Zhou CF, Wang ZS, Deng ZF, et al. 2007. Spartina invasion in China: Implications for invasive species management and future research. Weed Res. 47:183-91

Atwater BF, Conard SG, Dowden JN, Hedel CW, MacDonald RL, Savage W. 1979. History, landforms, and vegetation of the estuary's tidal marshes. In San Francisco Bay: The Urbanized Estuary, Investigations into the Natural History of San Francisco Bay and Delta with Reference to the Influence of Man, ed. TJ Conomos, AE Leviton, M Berson, pp. 347-85. San Francisco, CA: Pacific Division of the American Association for the Advancement of Science

Balletto JH, Heimbuch MV, Mahoney HJ. 2005. Delaware Bay salt marsh restoration: Mitigation for a power plant cooling water system in New Jersey, USA. Ecol. Eng. 25:204-13

Barras J, Beville S, Britsch D, Hartley S, Hawes S, et al. 2004. Historical and projected coastal Louisiana land changes: 1978-2050. USGS Open-File Report 03-334, 39 p.

Bartlett KB, Bartlett DS, Harriss RC, Sebacher DI. 1987. Methane emissions along a salt marsh salinity gradient. Biogeochemistry 4:183-202

Bertness MD, Crain CM, Holdredge C, Sala N. 2008. Eutrophication and consumer control of New England salt marsh primary productivity. Conserv. Biol. 22:131-39

Bertness MD, Ellison AM. 1987. Determinants of pattern in a New England salt marsh plant community. Ecol. Monogr. 57:129-47

Bertness MD, Ewanchuk PJ, Silliman BR. 2002. Anthropogenic modification of New England salt marsh landscapes. PNAS 99:1395-98 
Bertness MD, Silliman BR. 2008. Consumer control of salt marshes driven by human disturbance. Conserv. Biol. 22:618-23

Bockstael NE, Myrick Freeman III A, Kopp RJ, Portney PR, Smith VK. 2000. On measuring economic values for nature. Environ. Sci. Technol. 34:1384-89

Boesch DF, Turner RE. 1984. Dependence of fishery species on salt marshes: The role of food and refuge. Estuaries 7:460-68

Bortolus A, Iribarne O. 1999. Effects of the SW Atlantic burrowing crab Chasmagnathus granulata on a Spartina salt marsh. Mar. Ecol. Prog. Ser. 178:79-88

Bos D, Loonen MJJE, Stock M, Hofeditz F, Van Der Graaf AJ, Bakker JP. 2005. Utilisation of Wadden Sea salt marshes by geese in relation to livestock grazing. F. Nat. Conserv. 13:1-15

Bourn WS, Cottam C. 1950. Some Biological Effects of Ditching Tidewater Marshes. U.S. Dep. Int. Fish Wildl. Serv. Res. Rep. 19

Brewer JS, Levine JM, Bertness MD. 1998. Interactive effects of elevation and burial with wrack on plant community structure in some Rhode Island salt marshes. 7. Ecol. 86:125-36

Bridbury AR. 1955. England and the Salt Trade in the Later Middle Ages. New York: Oxford Univ. Press, $198 \mathrm{pp}$.

Bromberg KD, Bertness MD. 2005. Reconstructing New England salt marsh losses using historical maps. Estuaries 28:823-32

Brusati ED, Grosholz ED. 2006. Native and introduced ecosystem engineers produce contrasting effects on estuarine infaunal communities. Biol. Invasions 8:683-95

Buchsbaum R. 2001. Coastal marsh management. In Applied Wetlands Science and Technology, ed. D Kent, pp. 323-50. Boca Raton: Lewis Publisher

Butzer KW. 2002. French wetland agriculture in Atlantic Canada and its European roots: Different avenues to historical diffusion. Ann. Assoc. Am. Geogr: 92:451-70

Cahoon DR. 2006. A review of major storm impacts on coastal wetland elevations. Estuaries Coasts 29:889-98

Carlton JT. 1979. History, Biogeography, and Ecology of the Introduced Marine and Estuarine Invertebrates of the Pacific Coast of North America. Davis: Univ. California

Chambers RM, Meyerson LA, Saltonstall K. 1999. Expansion of Phragmites australis into tidal wetlands of North America. Aquat. Bot. 64:261-73

Chapman VJ. 1977. Introduction. In Wet Coastal Ecosystems, ed. VJ Chapman, pp. 1-30. New York: Elsevier

Chmura GL, Anisfeld SC, Cahoon DR, Lynch JC. 2003. Global carbon sequestration in tidal, saline wetland soils. Glob. Biogeochem. Cycles 17:1111-33

Clarke JA, Harrington BA, Hruby T, Wasserman FE. 1984. The effect of ditching for mosquito control on salt marsh use by birds in Rowley, Massachusetts. F. Field Ornithol. 55:160-80

Conesa HM, Jiménez-Cárceles FJ. 2007. The Mar Menor lagoon (SE Spain): A singular natural ecosystem threatened by human activities. Mar. Poll. Bull. 54:839-49

Conner WH, Day JW Jr, Baumann RH, Randall JM. 1989. Influence of hurricanes on coastal ecosystems along the northern Gulf of Mexico. Wetlands Ecol. Manag. 1:45-56

Costanza R, D’Arge R, DeGroot R, Farber S, Grasso M, et al. 1997. The value of the world's ecosystem services and natural capital. Nature 387:253-80

Costanza R, Wilson M, Troy A, Voinov A, Liu S. 2007. Valuing New Jersey's Natural Capital: An Assessment of the Economic Value of the State's Natural Resources. New Jersey: Department of Environmental Protection

Crain CM, Bromberg KD, Dionne M. 2008. Hydrologic alteration of New England tidal marshes by mosquito ditching and tidal restriction. In Antbropogenic Modification of North American Salt Marshes, ed. BR Silliman, MD Bertness, D Strong. In press

Crain CM, Silliman BR, Bertness SL, Bertness MD. 2004. Physical and biotic drivers of plant distribution across estuarine salinity gradients. Ecology 85:2539-49

Crooks JA. 2001. Assessing invader roles within changing ecosystems: Historical and experimental perspectives on an exotic mussel in an urbanized lagoon. Biol. Invasions 3:23-36

Crooks JA. 2002. Characterizing ecosystem-level consequences of biological invasions: The role of ecosystem engineers. Oikos 97:153-66

Crooks JA, Khim HS. 1999. Architectural vs biological effects of a habitat-altering, exotic mussel, Musculista senhousia. 7. Exp. Mar. Biol. Ecol. 240:53-75 
Czakó M, Feng X, He Y, Liang D, Márton L. 2006. Transgenic Spartina alterniflora for phytoremediation. Environ. Geochem. Health 28:103-10

Daehler CC, Strong DR. 1996. Status, prediction and prevention of introduced cordgrass Spartina spp. invasions in Pacific estuaries, USA. Biol. Conserv. 78:51-58

Daigh FC, MacCreary D, Stearns LA. 1938. Factors affecting the vegetative cover of Delaware marshes. Proc. N. 7. Mosq. Exterm. Comm. 25:209-16

Day JW Jr, Scarton F, Rismondo A, Are D. 1998. Rapid deterioration of a salt marsh in Venice Lagoon, Italy. 7. Coastal Res. 14:583-90

Deegan LA, Bowen JL, Drake D, Fleeger JW, Friedrichs CT, et al. 2007. Susceptibility of salt marshes to nutrient enrichment and predator removal. Ecol. Appl. 17:S42-63

Dijkema KS. 1987. Changes in salt-marsh area in the Netherlands Wadden Sea after 1600. In Vegetation Between Land and Sea, ed. AHL Huiskes, CWPM Blom, J Rozema. Boston, MA: Dr. W. Junk Publishers

Dijkema KS. 1990. Salt and brackish marshes around the Baltic Sea and adjacent parts of the North Sea: Their vegetation and management. Biol. Conserv. 51:191-209

Donnelly JP, Bertness MD. 2001. Rapid shoreward encroachment of salt marsh cordgrass in response to accelerated sea-level rise. Proc. Natl. Acad. Sci. 98:14218-23

Doody JP. 1992. The conservation of British saltmarshes. In Saltmarshes: Morphodynamics, Conservation and Engineering Significance, ed. LJR Allen, K Pye, pp. 184. Cambridge, UK: Cambridge Univ. Press

Erickson JE, Megonigal JP, Peresta G, Drake BG. 2007. Salinity and sea level mediate elevated $\mathrm{CO}_{2}$ effects on $\mathrm{C}_{3}-\mathrm{C}_{4}$ plant interactions and tissue nitrogen in a Chesapeake Bay tidal wetland. Glob. Change Biol. 13:202-15

Ewanchuk PJ, Bertness MD. 2004. The role of waterlogging in maintaining forb pannes in northern New England salt marshes. Ecology 85:1568-74

Ford MA, Grace JB. 1998. Effects of vertebrate herbivores on soil processes, plant biomass, litter accumulation and soil elevation changes in a coastal marsh. F. Ecol. 86:974-82

Ganong WF. 1903. The vegetation of the Bay of Fundy salt and diked marshes: an ecological study. Bot. Gaz. 36:161-86

Giblin AE, Bourg A, Valiela I, Teal JM. 1980. Uptake and losses of heavy metals in sewage sludge by a New England salt marsh. Am. F. Bot. 67:1059-68

Gough L, Grace JB. 1998. Effects of flooding, salinity and herbivory on coastal plant communities, Louisiana, United States. Oecologia 117:527-35

Hatvany MG. 2003. Marshlands: Four Centuries of Environmental Change on the Shores of the St. Lawrence. Quebec, Canada: Les Presses de l'Universite Laval. 184 pp.

Hazelden J, Boorman LA. 2001. Soils and 'managed retreat' in South East England. Soil Use Manag. 17:150-54

Hey DL. 2002. Nitrogen farming; Harvesting a different crop. Restoration Ecol. 10:1-10

Hoeksema RJ. 2007. Three stages in the history of land reclamation in The Netherlands. Irrig. Drain. 56:S11326

Hood WG. 2004. Indirect environmental effects of dikes on estuarine tidal channels: Thinking outside of the dike for habitat restoration and monitoring. Estuaries 27:273-82

Hulsman K, Dale PER, Kay BH. 1989. The runnelling method of habitat modification: An environmentfocused tool for salt marsh mosquito management. F. Am. Mosq. Control Assoc. 5:226-34

IPCC IPoCC, ed. 2007. Climate Change 2007: The Physical Science Basis. New York: Cambridge Univ. Press

Isacch JP, Holz S, Ricci L, Martinez MM. 2004. Post-fire vegetation change and bird use of a salt marsh in coastal Argentina. Wetlands 24:235-43

Jefferies RL. 1997. Long-term damage to subarctic coastal ecosystems by geese: ecological indicators and measures of ecosystem dysfunction. In Disturbance and Recovery in Arctic Lands: An Ecological Perspective, ed. RM Crawford. Boston: Springer

Jefferies RL, Perkins N. 1977. The effects on the vegetation of the additions of inorganic nutrients to salt marsh soils at Stiffkey, Norfolk. F. Ecol. 65:867-82

Jones CG, Lawton JH, Shachak M. 1997. Positive and negative effects of organisms as physical ecosystem engineers. Ecology 78:1946-57

Kearney MS, Grace RE, Stevenson JC. 1988. Marsh loss in Nanticoke Estuary, Chesapeake Bay. Geogr. Rev. 78:205-20 
Kiehl K, Esselink P, Bakker JP. 1997. Nutrient limitation and plant species composition in temperate salt marshes. Oecologia 111:325-30

King SE, Lester JN. 1995. The value of salt marsh as a sea defence. Mar. Poll. Bull. 30:180-89

Kiviat E, Hamilton E. 2001. Phragmites use by Native North Americans. Aquat. Bot. 69:341-57

Knottnerus OS. 2005. History of human settlement, cultural change and interference with the marine environment. Helgoland Mar. Res. 59:2-8

Kriwoken LK, Hedge P. 2000. Exotic species and estuaries: managing Spartina anglica in Tasmania, Australia. Ocean Coastal Manag. 43:573-84

Laszlo P. 2001. Salt: Grain of Life. New York: Columbia University Press. 193 pp.

Leendertse PC, Scholten MCT, Van Der Wal JT. 1996. Fate and effects of nutrients and heavy metals in experimental salt marsh ecosystems. Environ. Poll. 94:19-29

LeJemtel Hostle F. 2004. Poitou-Charentes: Gastronomy-A Cuisine Based on the Gifts of Surf and Turf. http://www.France.com/docs/111.html

Lenssen GM, Lamers J, Stroetenga M, Rozema J. 1993. Interactive effects of atmospheric $\mathrm{CO}_{2}$ enrichment, salinity and flooding on growth of $\mathrm{C}_{3}$ (Elymus athericus) and $\mathrm{C}_{4}$ (Spartina anglica) salt marsh species. Vegetatio 104/105:379-88

Lesser CR, Murphy FJ, Lake RW. 1976. Some effects of grid system mosquito control ditching on salt marsh biota in Delaware. Mosq. News 36:6977

Levin LA, Boesch DF, Covich A, Dahm C, Erséus C, et al. 2001. The function of marine critical transition zones and the importance of sediment biodiversity. Ecosystems 4:430-51

Levin LA, Neira C, Grosholz ED. 2006. Invasive cordgrass modifies wetland trophic function. Ecology 87:41932

Levin PS, Ellis J, Petrik R, Hay ME. 2002. Indirect effects of feral horses on estuarine communities. Conserv. Biol. 16:1364-71

Levine JM, Brewer JS, Bertness MD. 1998. Nutrients, competition and plant zonation in a New England salt marsh. 7. Ecol. 86:285-92

Lotze HK. 2005. Radical changes in the Wadden Sea fauna and flora over the last 2,000 years. Helgol. Mar. Res. 59:71-83

Lotze HK, Lenihan HS, Bourque BJ, Bradbury RH, Cooke RG, et al. 2006. Depletion, degradation, and recovery potential of estuaries and coastal seas. Science 312:1806-9

Magenheimer JF, Moore TR, Chmura GL, Daoust RJ. 1996. Methane and carbon dioxide flux from a macrotidal salt marsh, Bay of Fundy, New Brunswick. Estuaries 19:139-45

Meier D. 2004. Man and environment in the marsh area of Schleswig-Holstein from Roman until late Medieval times. Quat. Int. 112:55-69

Mendelssohn IA, Morris JT. 1999. Ecophysiological controls on the productivity of Spartina alterniflora. In Concepts and Controversies in Tidal Marsh Ecology, ed. M Weinstein, D Kreeger, pp. 59-80. Boston: Kluwer Academic Publishers

Michener WK, Blood ER, Bildstein KL, Brinson MM, Gardner LR. 1997. Climate change, hurricanes and tropical storms, and rising sea level in coastal wetlands. Ecol. Appl. 7:770-801

Minchinton TE, Bertness MD. 2003. Disturbance-mediated competition and the spread of Phragmites australis in a coastal marsh. Ecol. Appl. 13:1400-16

Minchinton TE, Simpson JC, Bertness MD. 2006. Mechanisms of exclusion of native coastal marsh plants by an invasive grass. 7. Ecol. 94:342-54

Mitsch WJ, Gosselink JG. 2000. Wetlands. New York: John Wiley \& Sons, 3rd edition

Moeller I, Spencer T, French JR. 1996. Wind wave attenuation over saltmarsh surfaces: Preliminary results from Norfolk, England. 7. Coast. Res. 12:1009-16

Morris JT, Sundareshwar PV, Nietch CT, Kjerfve B, Cahoon DR. 2002. Responses of coastal wetlands to rising sea level. Ecology 83:2869-77

Moy LD, Levin LA. 1991. Are Spartina marshes a replaceable resource? A functional approach to evaluation of marsh creation efforts. Estuaries 14:1-16

Neckles HA, Dionne M, Burdick DM, Roman CT, Buchsbaum R, Hutchins E. 2002. A monitoring protocol to assess tidal restoration of salt marshes on local and regional scales. Restor. Ecol. 10:556-63 
Neira C, Grosholz ED, Levin LA, Blake R. 2006. Mechanisms generating modification of benthos following tidal flat invasion by a Spartina hybrid. Ecol. App. 16:1391-1404

Nesbit DM. 1885. Tide marshes of the United States. Washington, DC: U.S. Dep. Agric. Sp. Rep. No. 7

Nieva FJJ, Castellanos EM, Castillo JM, Figueroa ME. 2005. Clonal growth and tiller demography of the invader cordgrass Spartina densiflora Brongn. at two contrasting habitats in SW European salt marsh. Wetlands 25:122-29

Nixon SW. 1980. Between coastal marshes and coastal waters-a review of twenty years of speculation and research on the role of salt marshes in estuarine productivity and water chemistry. In Estuarine and Wetland Processes, ed. P Hamilton, K MacDonald, pp. 437-523. New York: Plenum Publ. Corp.

Nixon SW. 1982. The ecology of New England high salt marshes: a community profile. Washington, DC: U.S. Dep. Int. Fish Wildl. Serv. FWS/OBS-81/55. 70 pp.

Odum EP. 1971. Fundamentals of Ecology. Philadelphia: Saunders

Odum WE. 1988. Comparative ecology of tidal freshwater and salt marshes. Annu. Rev. Ecol. Syst. 19:147-76

Orson RA. 1999. A paleoecological assessment of Phragmites australis in New England tidal marshes: changes in plant community structure during the last few millennia. Biol. Invasions 1:149-58

Pethick J. 2002. Estuarine and tidal wetland restoration in the United Kingdom: Policy versus practice. Restor. Ecol. 10:431-37

Pinder DA, Witherick ME. 1990. Port industrialization, urbanization and wetland loss. In Wetlands: A Threatened Landscape, ed. M Williams, pp. 235-66. Oxford, UK: Basil Blackwell

Portnoy JW. 1999. Salt marsh diking and restoration: Biogeochemical implication of altered wetland hydrology. Environ. Manag. 24:111-20

Portnoy JW, Giblin AE. 1997. Effects of historic tidal restrictions on salt marsh sediment chemistry. Biogeochemistry 36:275-303

Posey MH, Alphin TD, Powell CM. 1997. Plant and infaunal communities associated with a created marsh. Estuaries 20:42-47

Powers WL, Teeter TAH. 1922. Land Drainage. New York: John Wiley \& Sons, Inc.

Provost MW. 1977. Source reduction in salt-marsh mosquito control: past and future. Mosq. News 37:689-98

Ranwell DS. 1967. World resources of Spartina townsendii (sensu lato) and economic use of Spartina marshland. 7. Appl. Ecol. 4:239-56

Raposa KB, Roman CT, Heltshe JF. 2003. Monitoring nekton as a bioindicator in shallow estuarine habitats. Environ. Monit. Assess. 81:239-55

Raybould AF, Gray AJ, Lawrence MJ, Marshall DF. 1991. The evolution of Spartina anglica C.E. Hubbard (Gramineae): Genetic variation and status of the parental species in Britain. 7. Linn. Soc. 44:369-80

Reed A, Moisan G. 1971. The Spartina tidal marshes of the St. Lawrence Estuary and their importance to aquatic birds. Nat. Can. 98:905-21

Reise K. 2005. Coast of change: habitat loss and transformations in the Wadden Sea. Helgol. Mar. Res. 59:9-12

Resh VH. 2001. Mosquito control and habitat modification: case history studies of San Francisco Bay wetlands. In Bioassessment and Management of North American Freshwater Wetlands, ed. RB Rader, DP Batzer, SA Wissinger. New York: John Wiley \& Sons, Inc.

Rogers K, Saintilan N, Heijnis H. 2005. Mangrove encroachment of salt marsh in Western Port Bay, Victoria: The role of sedimentation, subsidence and sea level rise. Estuaries 28:551-59

Roman CT, Niering WA, Warren RS. 1984. Salt marsh vegetation change in response to tidal restriction. Environ. Manag. 8:141-50

Roman CT, Peck JA, Allen JR, King JW, Appleby PG. 1997. Accretion of a New England (U.S.A.) salt marsh in response to inlet migration, storms, and sea-level rise. Estuar. Coast. Shelf Sci. 45:717-27

Roman CT, Raposa KB, Adamowicz SC, James-Pirri J, Catena JG. 2002. Quantifying vegetation and nekton response to tidal restoration of a New England salt marsh. Restor. Ecol. 10:450-60

Rozema J, Dorel F, Janissen R, Lenssen G, Broekman R, et al. 1991. Effect of elevated atmospheric $\mathrm{CO}_{2}$ on growth, photosynthesis and water relations of salt marsh grass species. Aquat. Bot. 39:45-55

Rozema J, Leendertse P, Bakker JP, van Wijnen H. 2000. Nitrogen and vegetation dynamics in European salt marshes. In Concepts and Controversies in Tidal Marsh Ecology, ed. M Weinstein, pp. 469-91. Hingham, MA: Kluwer Academic Publishers 
Russell HS. 1976. A Long, Deep Furrow. Hanover, NH: Univ. Press of New England. 672 pp.

Saltonstall K. 2002. Cryptic invasion by a non-native genotype of the common reed, Phragmites australis, into North America. Proc. Natl. Acad. Sci. 99:2445-49

Sanlaville P. 2002. The deltaic complex of the lower Mesopotamian plain and its evolution through millennia. In The Iraqi Marshlands, ed. E Nicholson, P Clark, pp. 133-50. London, UK: AMAR Int. Charit. Found. Polit. Publi.

Seasholes NS. 2003. Gaining Ground. Boston, MA: MIT Press. 533 pp.

Sebold KR. 1992. From Marsh to Farm: The Landscape Transformation of Coastal New Jersey. Washington, DC: Natl. Park Serv., U.S. Dep. Int.

Sebold KR. 1998. The Low Green Prairies of the Sea: Economic Usage and Cultural Construction of the Gulf of Maine Salt Marshes. Orono, ME: Univ. Maine

Shisler JK, Jobbins DM. 1977. Salt marsh productivity as affected by the selective ditching technique, open marsh water management. Mosq. News 37:631-36

Shoreline Study. 2005. South San Francisco Bay Shoreline Study: Project Management Plan. Funded U.S. Army Corps Eng./Santa Clara Valley Water District/Calif. State Coastal Conservancy San Francisco

Shutes RBE. 2001. Artificial wetlands and water quality improvement. Environ. Int. 26:441-47

Silliman BR, Bertness MD. 2002. A trophic cascade regulates salt marsh primary production. Proc. Natl. Acad. Sci. 99:10500-5

Silliman BR, Bertness MD. 2004. Shoreline development drives invasion of Phragmites australis and the loss of plant diversity on New England salt marshes. Conserv. Biol. 18:1424-34

Silliman BR, Grosholz E, Bertness MD. 2008. A synthesis of anthropogenic impacts on North American salt marshes. In Anthropogenic Modification of North American Salt Marshes, ed. BR Silliman, MD Bertness, D Strong. In press

Silliman BR, Newell SY. 2003. Fungal-farming in a snail. Proc. Natl. Acad. Sci. 100:15643-48

Silliman BR, van de Koppel J, Bertness MD, Stanton LE, Mendelssohn IA. 2005. Drought, snails, and largescale die-off of southern U.S. salt marshes. Science 310:1803-6

Silliman BR, Zieman JC. 2001. Top-down control of Spartina alterniflora production by periwinkle grazing in a Virginia salt marsh. Ecology 82:2830-45

Smalley AE. 1960. Energy flow of a salt marsh grasshopper population. Ecology 41:672-77

Smith JB. 1904. Report N7 Agric. Exp. Stn. Mosquitoes Occurring Within the State, Their Habits, Life History, etc. Trenton, NJ: MacCrellish \& Quigley

Soukup MA, Portnoy JW. 1986. Impacts from mosquito control-induced sulphur mobilization in a Cape Cod estuary. Environ. Conserv. 13:47-50

Stearns LA, MacCreary D. 1936. Mosquito work in Delaware during 1933. Proc. N. F. Mosq. Exterm. Comm. 22:128-36

Sun S, Cai Y, Tian X. 2003. Salt marsh vegetation change after a short-term tidal restriction in the Changjiang Estuary. Wetlands 23:257-66

Suntornvongsagul K, Burke DJ, Hamerlynck EP, Hahn D. 2007. Fate and effects of heavy metals in salt marsh sediments. Environ. Poll. 149:79-91

Talley TS, Crooks JA, Levin LA. 2001. Habitat utilization and alteration by the invasive burrowing isopod Sphaeroma quoyanum, in California salt marshes. Mar. Biol. 138:561-73

Teal JM. 1962. Energy flow in the salt marsh ecosystem of Georgia. Ecology 43:614-24

Tiner RW, Swords JQ, McClain BJ. 2002. Wetland Status and Trends for the Hackensack Meadowlands. An Assessment Report from the U.S. Fish and Wildlife Service's National Wetlands Inventory Program. Hadley, MA: U.S. Fish Wildl. Serv., Northeast Reg.

Turner MG. 1987. Effects of grazing by feral horses, clipping, trampling and burning on a Georgia salt marsh. Estuaries 10:54-60

Turner RE. 1976. Geographic variations in salt marsh macrophyte production: A review. Contrib. Mar. Sci. 20:47-68

Turner RE. 1997. Wetland loss in the northern Gulf of Mexico: multiple working hypotheses. Estuaries 20:1-13

Turner RE, Baustian JJ, Swenson EM, Spicer JS. 2006. Wetland sedimentation from Hurricanes Katrina and Rita. Science 314:449-52 
Tyler AC, Lambrinos JG, Grosholz ED. 2007. Nitrogen inputs promote the spread of an invasive marsh grass. Ecol. Appl. 17:1886-98

UN Environ. Prog. (EP) 2006. Marine and Coastal Ecosystems and Human Well-being: A Synthesis Report Based on the Findings of the Millennium Ecosystem Assessment: Nairobi, Kenya: UNEP. 76 pp.

Valiela I, Peckol P, D’Avanzo C, Kremer J, Hersh D, et al. 1998. Ecological effects of major storms on coastal watersheds and coastal waters: Hurricane Bob on Cape Cod. 7. Coast. Res. 14:218-38

Valiela I, Teal JM. 1979. The nitrogen budget of a salt marsh ecosystem. Nature 280:652-56

Valiela I, Teal JM, Persson NY. 1976. Production and dynamics of experimentally enriched salt marsh vegetation: Belowground biomass. Limnol. Oceanogr. 21:245-52

Valiela I, Wright JE, Volkmann SB, Teal JM. 1977. Growth, production and energy transformations in the salt marsh killifish Fundulus heteroclitus (L.). Mar: Biol. 40:135-44

Van Dyke E, Wasson K. 2005. Historical ecology of a central California estuary: 150 years of habitat change. Estuaries 28:173-89

Vitousek PM, Mooney HA, Lubchenco J, Melillo JM. 1997. Human domination of Earth's ecosystems. Science 277:494-99

Ward LG, Kearney MS, Stevenson JC. 1998. Variations in sedimentary environments and accretionary patterns in estuarine marshes undergoing rapid submergence, Chesapeake Bay. Mar. Geol. 151

Warren RS, Niering WA. 1993. Vegetation change on a northeast tidal marsh: interaction of sea-level rise and marsh accretion. Ecology 74:96-103

Weis JS, Weis P. 2003. Is the invasion of the common reed, Phragmites australis, into tidal marshes of the eastern US an ecological disaster? Mar. Poll. Bull. 46:816-20

Weis JS, Weis P. 2004. Metal uptake, transport and release by wetland plants: implications for phytoremediation and restoration. Environ. Int. 30:685-700

Whitcraft CR, Talley DM, Crooks JA, Boland J, Gaskin J. 2007. Invasion of tamarisk (Tamarix spp.) in a southern California salt marsh. Biol. Invasions 9:875-79

Williams M. 2006. Deforesting the Earth. Chicago: Univ. Chicago Press. 520 pp.

Williams TP, Bubb JM, Lester JN. 1994. Metal accumulation within salt marsh environments: A review. Mar. Poll. Bull. 28:277-90

Windham L, Weis JS, Weis P. 2001. Patterns and processes of mercury release from leaves of two dominant salt marsh macrophytes, Phragmites australis and Spartina alterniflora. Estuaries 24:787-95

Yoshinobu S. 1998. Environment versus water control: The case of the southern Hangzhou Bay area from the mid-Tang through the Qing. In Sediments of Time: Environment and Society in Chinese History, ed. M Elvin, L Ts'ui-jung, pp. 135-64. New York: Cambridge Univ. Press

Zedler JB. 1996. Coastal mitigation in southern California: The need for a regional restoration strategy. Ecol. Appl. 6:84-93

Zedler JB, Kercher S. 2004. Causes and consequences of invasive plants in wetlands: opportunities, opportunists, and outcomes. Crit. Rev. Plant Sci. 23:431-52 
Annual Review of Marine Science

Volume 1, 2009

\section{Contents}

Wally's Quest to Understand the Ocean's $\mathrm{CaCO}_{3}$ Cycle

W.S. Broecker

A Decade of Satellite Ocean Color Observations

Charles R. McClain

Chemistry of Marine Ligands and Siderophores

Fulia M. Vraspir and Alison Butler

Particle Aggregation

Adrian B. Burd and George A. Fackson

Marine Chemical Technology and Sensors for Marine Waters:

Potentials and Limits

Tommy S. Moore, Katherine M. Mullaugh, Rebecca R. Holyoke,

Andrew S. Madison, Mustafa Yücel, and George W. Luther, III

Centuries of Human-Driven Change in Salt Marsh Ecosystems

K. Bromberg Gedan, B.R. Silliman, and M.D. Bertness ....

Macro-Ecology of Gulf of Mexico Cold Seeps

Erik E. Cordes, Derk C. Bergquist, and Charles R. Fisher

Ocean Acidification: The Other $\mathrm{CO}_{2}$ Problem

Scott C. Doney, Victoria 7. Fabry, Richard A. Feely, and foan A. Kleypas

Marine Chemical Ecology: Chemical Signals and Cues Structure

Marine Populations, Communities, and Ecosystems

Mark E. Hay

Advances in Quantifying Air-Sea Gas Exchange and Environmental

Forcing

Rik Wanninkhof, William E. Asher, David T. Ho, Colm Sweeney, and Wade R. McGillis 
Atmospheric Iron Deposition: Global Distribution, Variability, and Human Perturbations

Natalie M. Mahowald, Sebastian Engelstaedter, Chao Luo, Andrea Sealy,

Paulo Artaxo, Claudia Benitez-Nelson, Sophie Bonnet, Ying Chen, Patrick Y. Chuang,

David D. Coben, Francois Dulac, Barak Herut, Anne M. Johansen, Nilgun Kubilay,

Remi Losno, Willy Maenhaut, Adina Paytan, Joseph M. Prospero,

Lindsey M. Shank, and Ronald L. Siefert

Contributions of Long-Term Research and Time-Series Observations

to Marine Ecology and Biogeochemistry

Hugh W. Ducklow, Scott C. Doney, and Deborah K. Steinberg

Clathrate Hydrates in Nature

Keith C. Hester and Peter G. Brewer

Hypoxia, Nitrogen, and Fisheries: Integrating Effects Across Local

and Global Landscapes

Denise L. Breitburg, Darryl W. Hondorp, Lori A. Davias, and Robert F. Diaz.......

The Oceanic Vertical Pump Induced by Mesoscale

and Submesoscale Turbulence

Patrice Klein and Guillaume Lapeyre

An Inconvenient Sea Truth: Spread, Steepness, and Skewness

of Surface Slopes

Walter Munk

Loss of Sea Ice in the Arctic

Donald K. Perovich and Facqueline A. Richter-Menge ...

Larval Dispersal and Marine Population Connectivity

Robert K. Cowen and Su Sponaugle

\section{Errata}

An online log of corrections to Annual Review of Marine Science articles may be found at http://marine.annualreviews.org/errata.shtml 